\title{
ANALISIS LAPORAN ARUS KAS UNTUK MENILAI KINERJA KEUANGAN PADA PT GUDANG GARAM, TBK YANG TERDAFTAR DI BURSA EFEK INDONESIA
}

\author{
Oleh: \\ Lia Agustina \\ S1 Akuntansi \\ Liper Siregar, Parman Tarigan, Ady Inrawan
}

\begin{abstract}
Abstrak
Tujuan dari penelitian ini adalah untuk mengetahui gambaran laporan arus kas dan kinerja keuangan serta mengetahui dan menganalisis faktor yang menyebabkan kinerja keuangan PT Gudang Garam, Tbk yang terdaftar di Bursa Efek Indonesia menurun. Objek penelitian ini adalah PT Gudang Garam, Tbk yang terdaftar di Bursa Efek Indonesia tahun 2011-2015. Jenis data yang digunakan adalah data kualitatif dan data kuantitatif, sumber data adalah data sekunder, dan teknik pengumpulan data adalah dengan metode dokumentasi. Metode analisis yang digunakan dalam penelitian ini adalah metode analisis deskriptif kualitatif dan metode komparatif.

Hasil penelitian dapat disimpulkan bahwa kinerja keuangan PT Gudang Garam, Tbk yang terdaftar di Bursa Efek Indonesia berdasarkan keseluruhan dari hasil analisis rasio likuiditas keuangan, fleksibilitas keuangan dan arus kas bebas perusahaan belum baik. Hal ini disebabkan oleh kenaikan kewajiban lancar lebih besar dibandingkan dengan kas bersih yang diperoleh dari aktivitas operasi dan semakin besarnya total kewajiban yang harus dibiayai perusahaan menggunakan kas bersih yang diperoleh dari aktivitas operasi. PT Gudang Garam, Tbk sebaiknya mempercepat periode panagihan piutang dan periode perputaran persediaan untuk meningkatkan kas bersih yang diperoleh dari aktivitas operasi dan pengembalian kewajiban lancar semakin cepat.
\end{abstract}

Kata Kunci: Laporan Arus Kas dan Kinerja Keuangan

\section{Abstract}

The purpose of this research are to identify the description of cash flows and financial perfomance and to know and analyze the factors that caused financial performance on PT Gudang Garam, Tbk which listed in Indonesia Stock Exchange decreasing. The object of this research is PT Gudang Garam, Tbk which listed in the Indonesia Stock Exchange from 2011 until 2015. The kind of data is using qualitative data and quantitative data. The data source is secondary data and the data gatherer technique is with documentation method. Method of analysis data in this research are descriptive qualitative analysis and comparative method.

The result can concluded that financial performance of PT Gudang Garam, Tbk which listed in Indonesia Stock Exchange based on financial liquidity ratio, financial flexibility ratio and free cash flow ratio is not good. This is caused by current liability is bigger than net cash earned from operating activities and the more the amount of the total of liabilities to be financed companies using net cash earned from activities operation. PT Gudang Garam, Tbk should be accelerate receivable colletion period and inventory turnover to increase net cash earned from operating activies and make current liabilities return more fast.

Keywords: Cash flow report and Financial performance

\section{A. PENDAHULUAN}

1. Latar Belakang Masalah

Dalam perkembangan dunia usaha yang semakin maju, persaingan antara satu perusahaan dengan perusahaan lainnya semakin tinggi mengakibatkan adanya perusahaan yang tiba-tiba mengalami kemunduran. Oleh karena itu, agar perusahaan dapat bertahan dan biasa tumbuh berkembang, perusahaan harus mencermati kondisi dan kinerja perusahaan. Untuk mengetahui dengan tepat bagaimana kondisi dan kinerja perusahaan maka dibutuhkan pula suatu analisis yang tepat. Melalui hasil analisis tersebut, dapat diketahui penggunaan sumbersumber ekonomi, kewajiban yang harus dipenuhi dan modal yang dimiliki oleh perusahaan, serta hasil-hasil yang telah dicapai perusahaan tersebut.

Perusahaan harus mencermati dan menganalisis kinerja perusahaan agar dapat bertahan, salah satunya adalah dengan melakukan analisis kinerja dari sisi keuangan terhadap laporan keuangan. Salah satu cara untuk mengukur tingkat kinerja perusahaan adalah dengan menggunakan laporan arus kas. 
Penilaian kinerja suatu perusahaan dapat dilakukan dengan menganalisis dua aspek, yaitu kinerja finansial dan kinerja nonfinansial. Kinerja finansial dapat dilihat melalui data-data laporan keuangan, sedangkan kinerja nonfinansial dapat dilihat melalui aspek-aspek nonfinansial diantaranya aspek pemasaran, aspek teknologi maupun aspek manajemen.

Perusahaan wajib menyusun laporan arus kas dan menyajikannya sebagai bagian yang tak terpisahkan dari laporan keuangan untuk setiap periode penyajian laporan keuangan. Informasi arus kas suatu perusahaan berguna bagi para pemakai laporan keuangan sebagai dasar untuk menilai kemampuan perusahaan dalam menghasilkan kas dan menilai kebutuhan perusahaan untuk menggunakan arus kas.

Laporan arus kas adalah suatu laporan tentang aktivitas penerimaan dan pengeluaran kas perusahaan di dalam suatu periode tertentu, beserta penjelasan tentang sumbersumber penerimaan dan pengeluaran kas tersebut. Tujuan utama dari laporan arus kas adalah melaporkan penerimaan kas, pembayaran kas, dan perubahan bersih kas dari kegiatan operasi, investasi, serta pembiayaan perusahaan selama suatu periode, dalam bentuk yang dapat merekonsiliasi saldo kas awal dan akhir.

\section{Rumusan Masalah}

a. Bagaimana gambaran likuiditas, fleksibilitas, arus kas bebas dan kinerja keuangan pada PT Gudang Garam, Tbk yang terdaftar di Bursa Efek Indonesia?

b. Faktor apa yang menyebabkan kinerja keuangan PT Gudang Garam, Tbk yang terdaftar di Bursa Efek Indonesia kurang baik?

\section{Tujuan Penelitian}

a. Untuk mengetahui gambaran likuiditas, fleksibilitas, arus kas bebas dan kinerja keuangan pada PT Gudang Garam, Tbk yang terdaftar di Bursa Efek Indonesia.

b. Untuk mengetahui dan menganalisis faktor yang menyebabkan kinerja keuangan PT Gudang Garam, Tbk yang terdaftar di Bursa Efek Indonesia kurang baik.

\section{Metode Penelitian}

Dalam penelitian ini, penulis mengambil objek penelitian pada PT Gudang Garam, Tbk yang terdaftar di Bursa Efek Indonesia dengan cara mengakses data dari situs www.idx.co.id.

Adapun desain penelitian yang digunakan dalam penulisan skripsi ini adalah penelitian kepustakaan (library research). Teknik pengumpulan data yang dilakukan penulis dalam penelitian ini adalah dokumentasi. Adapun jenis data yang digunakan dalam penelitian ini adalah jenis data kualitatif dan data kuantitatif. Hasil data yang diperoleh akan dianalisis secara deskriptif yaitu analisis deskriptif kualitatif dan metode komparatif.

\section{B. LANDASAN TEORI}

\section{Laporan Keuangan}

Menurut Baridwan (2004:17), laporan keuangan merupakan ringkasan dari proses pencatatan transaksi-transaksi keuangan yang terjadi selama dua tahun buku yang bersangkutan.

Menurut Rudianto (2012:17), laporan keuangan terdiri dari komponen-komponen berikut ini:

a. Laporan Laba Rugi Komprehensif (Statement of Comprehensif Income), yaitu laporan yang menunjukkan kemampuan perusahaan dalam menghasilkan laba selama suatu periode akuntansi atau satu tahun.

b. Laporan Perubahan Ekuitas (Statement of Changes in Equity), adalah laporan yang menunjukkan perubahan hak residu atas aset perusahaan setelah dikurangi semua kewajiban.

c. Laporan Posisi Keuangan (Statement of Financial Position), adalah daftar yang menunjukkan posisi sumberdaya yang dimiliki perusahaan, serta informasi dari mana sumber daya tersebut diperoleh.

d. Laporan Arus Kas (Statement of Cash Flows), adalah laporan yang menunjukkan aliran uang yang diterima dana yang digunakan perusahaan selama satu periode akuntansi, beserta sumber-sumbernya.

e. Catatan Atas Laporan Keuangan, adalah informasi tambahan yang harus diberikan menyangkut berbagai hal yang terkait secara langsung dengan laporan keuangan yang disajikan entitas tertentu, seperti kebijakan akuntansi yang digunakan perusahaan, dan berbagai informasi yang relevan dengan laporan keuangan tersebut.

\section{Analisis Laporan Arus Kas}

Laporan arus kas adalah salah satu dari tiga laporan keuangan yang disusun oleh perusahaan. Menurut Martani, dkk (2012:145), laporan arus kas adalah laporan yang menyajikan informasi tentang arus kas masuk dan arus kas keluar dan setara kas suatu entitas untuk suatu periode tertentu.

Menurut PSAK 2 (revisi 2009) dalam Martani, dkk (2012:146), laporan arus kas, tiga klasifikasi dalam arus kas yaitu sebagai berikut:

a. Aktivitas Operasi adalah aktivitas penghasil utama pendapatan entitas dan aktivitas lain yang bukan merupakan aktivitas investasi dan pendanaan. 
b. Aktivitas Investasi adalah aktivitas berupa perolehan dan pelepasan aset jangka panjang serta investasi lain yang tidak termasuk setara kas.

c. Aktivitas Pendanaan adalah aktivitas yang mengakibatkan perubahan dalam jumlah serta komposisi kontribusi modal dan pinjaman entitas.

Dalam menganalisis laporan arus kas, terdapat beberapa rasio yang digunakan. Suatu rasio mengekspresikan hubungan matematis antara suatu kuantitas dengan kuantitas lainnya. Menurut Kieso, Weygandt, dan Warfield (2002:243), untuk menilai kinerja keuangan melalui laporan arus kas digunakan rasio sebagai berikut:

a. Rasio Likuiditas Keuangan

Menurut Kasmir (2010:110), rasio likuiditas keuangan yaitu rasio yang menggambarkan kemampuan perusahaan memenuhi kemampuan jangka pendeknya.

Menurut Kieso, Weygand, dan Warfield (2002:243), salah satu rasio yang sering digunakan untuk menilai likuiditas adalah rasio cakupan hutang tunai lancar (current cash debt coverage ratio). Rasio ini mengindikasikan apakah perusahaan dapat melunasi kewajiban lancarnya dalam tahun tertentu dari operasinya.

Rasio Cakupan Hutang Tunai Lancar $=\frac{\text { Kas Bersilh yang Disediaksn olph }}{\text { Kewaititivan Lancas Operata-rata }}$

\section{Keterangan:}

- Kas Bersin yang Disediakan $=$ Laba Bersh - Kenakan Pitang Usaha deh Abtivitas Operasi - Kenaikan Persedian

- Kewaidan Lancar Rata-rata = Kewajosan Lancar Tahun Keselunhan dibagi dengan umiat
data

b. Rasio Fleksibilitas Keuangan

Menurut Wild, Subramanyam, dan Halsey (2005:206), rasio fleksibilitas keuangan merupakan kemampuan suatu perusahaan untuk mengambil langkah guna mengatasi interupsi yang tidak diharapkan pada arus dana.

Menurut Kieso, Weygand, dan Warfield (2002:243), ukuran yang lebih bersifat jangka panjang dan menyediakan informasi mengenai fleksibilitas keuangan adalah rasio cakupan hutang tunai (cash debt coverage ratio). Rasio ini mengidentifikasikan kemampuan perusahaan untuk membayar kembali kewajibannya dengan kas bersih yang disediakan oleh aktivitas operasi, tanpa harus melikuidasi aktiva yang dipakai dalam operasi.

$$
\text { Rasio Cakupan Hutang Tunai }=\frac{\begin{array}{l}
\text { Kas Bersih yane Disediakan } \\
\text { oleh Aktivitas Operasi }
\end{array}}{\text { Total Kowajtban Rata-rata }}
$$$$
\text { Keterangan }
$$$$
\begin{aligned}
& \text { Ju } \\
& \text {. Kas Bessih yang Disediakan }= \\
& \text { oleh Aktivitas Operasi }
\end{aligned}
$$$$
\text { Total Kewaiban Tahun }
$$$$
\text { - Total Kewajban Rata }- \text { rata }=\text { Keselunuhan dibagi dengan jumbar }
$$

c. Rasio Arus Kas Bebas

Arus kas bebas positif mencerminkan jumlah yang tersediah bagi aktivitas bisnis setelah penyisihan untuk pendanaan dan investasi yang diperlukan untuk mempertahankan kapasitas produksi pada tingkat sekarang. Menurut Kieso, Weygand, dan Warfield (2002:243), cara yang lebih canggih untuk memeriksa fleksibilitas keuangan perusahaan adalah mengembangkan analisis arus kas bebas. Analisis ini dimulai dengan kas bersih yang disediakan oleh aktivitas operasi dan berakhir pada arus kas bebas (free cash flow), yang dihitung sebagai kas bersih yang disediakan oleh aktivitas operasi dikurangi pengeluaran modal dan dividen.

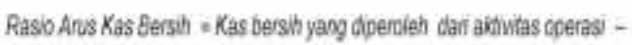

veroteluaran modal - penbayasn ofuden

Keterangan.

- Kas Bersh yang Disedakan = Libu Bessh - Kenakan Putang Usata -

deh Alfivitas Operas Keakan Persedas:

- Pengeluaran Modal. $=$ Pembelian Peralatan dan Tanah

\section{Kinerja Keuangan}

Menurut Mulyadi (2001:359), penilaian kinerja adalah penentuan secara periodik efektivitas oprasional suatu organisasi bagian organisasi dan persoalannya berdasarkan sasaran, standar dan kinerja yang telah di tetapkan sebelumnya. Menurut Rudianto (2013:189), kinerja keuangan merupakan hasil atau prestasi yang telah dicapai oleh manajemen perusahaan dalam menjalankan fungsinya mengelolah aset perusahaan secara efektif selama periode tertentu.

Penilaian kondisi perusahaan dan kinerja perusahaan memerlukan tolak ukur. Tolak ukur yang sering digunakan adalah arus kas yang terdiri dari aktivitas operasi, aktivitas investasi, dan aktivitas pendanaan. Analisis laporan arus kas sangat perlu dilakukan karena kreditor akan memeriksa laporan arus kas apakah perusahaan mampu melunasi pinjamannya, berdasarkan dari kas bersih yang diterima dari aktivitas operasi. Dalam hal ini laporan arus kas memberikan pandangan yang lebih baik untuk menilai kondisi perusahaan dan kinerja keuangan.

4. Hubungan Laporan Arus Kas dengan Kinerja Keuangan

Untuk mengevaluasi kondisi dan kinerja keuangan suatu perusahaan harus menggunakan tolak ukur. Tolak ukur yang 
digunakan adalah rasio likuiditas keuangan, rasio fleksibilitas keuangan, dan rasio arus kas bebas.

Rasio likuiditas keuangan, menurut Kieso, Weygand dan Warfield (2002:243), semakin tinggi rasio ini, semakin kecil kemungkinan perusahaan akan memiliki masalah likuiditas. Rasio yang mendekati 1:1 adalah bagus karena mengindikasikan bahwa perusahaan dapat memenuhi semua kewajiban lancarnya dari arus kas yang dihasilkan secara internal dan atau dengan kata lain rasio $\geq 1$ kinerja keuangan dikatakan baik.

Rasio fleksibilitas, semakin tinggi rasio ini semakin kecil kemungkinan perusahaan akan mengalami kesulitan dalam memenuhi kewajibannya pada saat jatuh tempo. Akibatnya, rasio ini menandakan apakah perusahaan dapat membayar hutanghutangnya dan bertahan hidup jika sumber dana eksternal terbatas atau terlalu mahal dan atau dengan kata lain rasio $\geq 1$ kinerja keuangan dikatakan baik.

Rasio arus kas bebas, mengindikasikan bahwa semakin besar jumlah arus kas bebas semakin besar tingkat fleksibilitas keuangan perusahaan. Menurut Wild, Subramanyam, dan Halsey (2005:23), arus kas bebas positif mencerminkan jumlah yang tersediah bagi aktivitas bisnis setelah penyisihan untuk pendanaan dan investasi yang diperlukan untuk mempertahankan kapasitas produksi pada tingkat sekarang. Pertumbuhan fleksibilitas keuangan bergantung pada ketersediaan arus kas bebas. Dengan kata lain rasio $\geq 0$ kinerja keuangan dikatakan baik.

\section{PEMBAHASAN}

1. Analisa

a. Rasio Likuiditas Keuangan PT Gudang Garam, Tbk yang Terdaftar di Bursa

\section{Efek Indonesia}

Berdasarkan hasil analisis, diperoleh bahwa dari tahun ke tahun nilai likuiditas keuangan PT Gudang Garam, Tbk di bawah standar $\leq 1$. Artinya bahwa jumlah atau nilai kas dari operasional tidak mampu memenuhi kewajiban jangka pendeknya.

Dilihat dari kecenderungannya ataupun trennya bahwa likuiditas keuangan PT Gudang Garam, Tbk cenderung meningkat dari tahun 2012, 2013 dan 2015. Walaupun likuiditas keuangan tahun 2013 menurun dari tahun 2012, tetapi nilai likuiditas ini masih di atas ratarata dan lebih besar dari tahun 2011 dan 2014. Dengan kata lain likuiditas keuangan PT Gudang Garam, Tbk semakin membaik. Dilihat dari rata-rata nilai likuiditas keuangan dari tahun 2011 sampai 2015 sebesar 0,118 yang artinya bahwa setiap Rp 1 kewajiban lancar dijamin dengan $\mathrm{Rp}$ 0,118 kas bersih yang dihasilkan dari aktivitas operasi. Nilai likuiditas keuangan
PT Gudang Garam, Tbk terendah terjadi pada tahun 2011, tertinggi terjadi pada tahun 2012. Sedangkan untuk nilai likuiditas keuangan tahun 2011 dan 2014 di bawah rata-rata.

Berdasarkan hasil analisis, dapat disimpulkan bahwa kinerja keuangan PT Gudang Garam, Tbk dari tahun 2011-2015 cenderung mengalami peningkatan namun peningkatan ini masih di bawah standar $\leq 1$.

Nilai likuiditas keuangan PT Gudang Garam, Tbk terendah terjadi pada tahun 2011. Hal ini disebabkan oleh penerimaan kas dari pelanggan lebih kecil daripada peningkatan pembayaran kas kepada pemasok dan karyawan selalu meningkat dari tahun ke tahun. Dalam pembayaran bunga juga mengalami peningkatan ditambah lagi pembayaran pajak penghasilan badan di tahun 2011 merupakan jumlah yang paling tinggi dibandingkan tahuntahun yang lain.

\section{b. Rasio Fleksibilitas Keuangan PT Gudang Garam, Tbk yang Terdaftar di Bursa Efek Indonesia}

Berdasarkan hasil analisis, diperoleh bahwa dari tahun ke tahun nilai fleksibilitas keuangan PT Gudang Garam, Tbk di bawah standar $\leq 1$. Artinya bahwa jumlah atau nilai kas dari aktivitas operasional tidak mampu memenuhi kewajiban jangka pendeknya.

Dilihat dari kecenderungannya ataupun trennya bahwa fleksibilitas keuangan PT Gudang Garam, Tbk cenderung meningkat dari tahun 2012, 2013 dan 2015. Walaupun likuiditas keuangan tahun 2013 menurun dari tahun 2012, tetapi nilai fleksibilitas keuangan masih di atas rata-rata dan lebih besar dari tahun 2011 dan 2014. Dengan kata lain likuiditas keuangan PT Gudang Garam, Tbk semakin membaik. Dilihat dari rata-rata nilai fleksibilitas keuangan dari tahun 2011 sampai 2015 sebesar 0,110 yang artinya bahwa setiap Rp 1 kewajiban lancar dijamin dengan $R p 0,110$ kas bersih yang dihasilkan dari aktivitas operasi. Nilai likuiditas keuangan PT Gudang Garam, Tbk terendah terjadi pada tahun 2011, tertinggi terjadi pada tahun 2012. Sedangkan untuk nilai fleksibilitas keuangan tahun 2011 dan 2014 di bawah rata-rata.

Berdasarkan hasil analisis, dapat disimpulkan bahwa kinerja keuangan PT Gudang Garam, Tbk dari tahun 2011-2015 cenderung mengalami peningkatan dan di atas rata-rata. Nilai terendah terjadi pada tahun 2011. Hal ini disebabkan peningkatan penerimaan kas dari pelanggan lebih kecil daripada peningkatan pembayaran kas kepada pemasok dan karyawan, ditambah lagi pembayaran pajak penghasilan badan di tahun 2011 merupakan jumlah yang paling tinggi dibandingkan tahun-tahun yang lain. 


\section{c. Rasio Arus Kas Bebas PT Gudang Garam, Tbk yang Terdaftar di Bursa Efek Indonesia \\ Hasil analisis data menunjukkan bahwa} arus kas bebas PT Gudang Garam, Tbk dari tahun ke tahun di bawah standar $\leq 0$, yang artinya bahwa PT Gudang Garam, Tbk tidak mampu mendanai kegiatan investasi dan pendanaannya dengan kas bersih yang diperoleh dari aktivitas operasi.

Dilihat dari kecenderungannya bahwa arus kas bebas PT Gudang Garam, Tbk cenderung meningkat, namun rata-rata memiliki nilai negatif. Dengan kata lain arus kas bebas PT Gudang Garam, Tbk semakin membaik. Jika dilihat dari rata-rata arus kas bebas dari tahun 2011 sampai tahun 2015 memiliki nilai -3.646.219, yang artinya bahwa setiap $R p 1$ kegiatan investasi dan pendanaan dijamin dengan $\mathrm{Rp}-3.646 .219$ kas bersih yang diperoleh dari aktivitas operasi. Nilai terendah terjadi pada tahun 2011. Tahun 2013, dan tahun 2014 di bawah rata-rata dan di bawah standar $\leq 0$.

Berdasarkan hasil analisis, dapat disimpulkan bahwa arus kas bebas PT Gudang Garam, Tbk terendah terjadi 2014. Pada tahun 2014 juga terjadi penurunan arus kas bebas yang cukup drastis dari tahun 2013. Hal ini disebabkan karena terjadinya kenaikan pada pembayaran dividen dan pengeluaran kas. Sedangkan kas bersih yang diperoleh dari aktivitas operasi yang digunakan untuk kegiatan tersebut mengalami penurunan.

\section{d. Kinerja Keuangan PT Gudang Garam, Tbk yang Terdaftar di Bursa Efek Indonesia}

Hasil penelitian yang telah dilakukan pada PT Gudang Garam, Tbk yang terdaftar di Bursa Efek Indonesia dapat diketahui bahwa:

1) Likuiditas PT Gudang Garam, Tbk dari tahun 2011 sampai 2015 cenderung mengalami peningkatan namun peningkatan ini masih di bawah standar $\leq$ 1. Nilai likuiditas keuangan PT Gudang Garam, Tbk terendah terjadi pada tahun 2011. Hal ini disebabkan oleh penerimaan kas dari pelanggan lebih kecil daripada peningkatan pembayaran kas kepada pemasok dan karyawan selalu meningkat dari tahun ke tahun. Dalam pembayaran bunga juga mengalami peningkatan ditambah lagi pembayaran pajak penghasilan badan di tahun 2011 merupakan jumlah yang paling tinggi dibandingkan tahun-tahun yang lain.

2) Fleksibilitas PT Gudang Garam, Tbk dari tahun 2011 sampai 2015 cenderung mengalami peningkatan dan di atas ratarata. Nilai terendah terjadi pada tahun 2011. Hal ini disebabkan oleh semakin besarnya total kewajiban yang harus dibiayai perusahaan menggunakan kas bersih yang diperoleh dari aktivitas operasi.

3) Arus kas bebas PT Gudang Garam, Tbk terendah terjadi tahun 2014. Pada tahun 2014 juga terjadi penurunan arus kas bebas yang cukup drastis dari tahun 2013. Hal ini disebabkan karena terjadinya kenaikan pada pembayaran dividen dan pengeluaran kas. Sedangkan kas bersih yang diperoleh dari aktivitas operasi yang digunakan untuk kegiatan tersebut mengalami penurunan.

Berdasarkan uraian di atas, dapat disimpulkan bahwa kinerja keuangan PT Gudang Garam, Tbk yang terdaftar di Bursa Efek Indonesia yang dianalisis dengan rasio likuiditas, fleksibilitas dan arus kas bebas cenderung meningkat, namun masih kurang baik. Hal ini disebabkan faktor penerimaan kas dari pelanggan, pembayaran kas kepada pemasok dan karyawan yang selalu meningkat menyebabkan kinerja Keuangan pada PT Gudang Garam, Tbk yang terdaftar di Bursa Efek Indonesia menjadi kurang baik.

\section{Evaluasi}

\section{a. Rasio Likuiditas Keuangan PT Gudang Garam, Tbk yang Terdaftar di Bursa Efek Indonesia}

Berdasarkan hasil analisis, rasio likuiditas keuangan pada PT Gudang Garam, Tbk yang terdaftar di Bursa Efek Indonesia tahun 20112015 berfluktuasi cenderung meningkat. Tahun 2012, tahun 2013 dan tahun 2015 berada di atas rata-rata, sedangkan tahun 2011 dan tahun 2015 di bawah rata-rata. Walaupun likuiditas keuangan PT Gudang Garam, Tbk cenderung mengalami peningkatan. Namun rata-rata masih di bawah standar $\leq 1$, yang artinya perusahaan belum mampu memenuhi kewajiban lancarnya yang segerah jantuh tempo dengan kas bersih yang dihasilkan dari aktivitas operasi.

Nilai likuiditas keuangan PT Gudang Garam, Tbk terendah terjadi pada tahun 2011 dan di bawah rata-rata. Di tahun 2014 ini juga terjadinya penurunan nilai likuiditas dari tahun sebelumnya. Penurunan disebabkan penerimaan kas dari pelanggan lebih kecil daripada peningkatan pembayaran kas kepada pemasok dan karyawan selalu meningkat dari tahun ke tahun. Dalam pembayaran bunga juga mengalami peningkatan ditambah lagi pembayaran pajak penghasilan badan di tahun 2011 merupakan jumlah yang paling tinggi dibandingkan tahun-tahun yang lain. Untuk meningkatkan kemampuan PT Gudang Garam, Tbk memenuhi kewajiban lancarnya dengan kas bersih yang diperoleh dari aktivitas operasi. Sebaiknya perusahaan lebih memperhatikan lagi keadaan yang lebih baik saat akan 
melakukan pinjaman kepada pihak yang berkepentingan agar kas bersih yang dihasilkan dari aktivitas operasi bisa disesuaikan untuk memenuhi kewajiban perusahaan saat operasi.

\section{b. Rasio Fleksibilitas Keuangan PT Gudang Garam, Tbk yang Terdaftar di Bursa Efek Indonesia}

Berdasarkan hasil analisis, rasio fleksibilitas keuangan pada PT Gudang Garam, Tbk yang terdaftar di Bursa Efek Indonesia tahun 2011 sampai 2015 berfluktuasi cenderung meningkat. Rasio fleksibilitas keuangan PT Gudang Garam, Tbk dinyatakan kurang baik karena di bawah standar $\leq 1$.

Tahun 2011 dan 2014 di bawah rata-rata, sedangkan tahun 2012, tahun 2013, dan tahun 2015 di atas rata-rata. Tahun terendah terjadi pada tahun 2011. Hal ini disebabkan peningkatan penerimaan kas dari pelanggan lebih kecil daripada peningkatan pembayaran kas kepada pemasok dan karyawan, ditambah lagi pembayaran pajak penghasilan badan di tahun 2011 merupakan jumlah yang paling tinggi dibandingkan tahun-tahun yang lain.

Berdasarkan hasil analisis, secara keseluruhan fleksibilitas keuangan cenderung meningkat dari tahun ke tahun. Penurunan yang cukup tinggi terjadi pada tahun 2011 dan 2014 dikarenakan kenaikan total kewajiban lebih tinggi dibandingkan kas bersih yang diperoleh dari aktivitas operasi. Hal ini mengakibatkan semakin kecil kemampuan PT Gudang Garam, Tbk membayaran total kewajiban rata-rata. Fleksibilitas keuangan cenderung dibawah ratarata dan di bawah standar $\geq 1$. Untuk meningkatkan fleksibilitas keuangan sebaiknya perusahaan meningkatkan penjualan tunai dibandingkan dengan penjualan kredit agar kas bersih yang diperoleh dari aktivitas operasi semakin tinggi. Sebaiknya perusahaan dapat mengurangi pembayaran kas kepada pemasok agar dapat mengurangi penimbunan kelebihan persedian dalam perusahaan tersebut karena pembayaran kas kepada pemasok selalu meningkat dari tahun 2011 sampai tahun 2015 . Dan pihak manajemen harus lebih memperhatikan pengeluaran hutang dalam perusahaan agar perusahaan mengetahui seberapa besar pinjaman yang diberikan perusahaan kepada nasabah.

\section{c. Rasio Arus Kas Bebas PT Gudang Garam, Tbk yang Terdaftar di Bursa Efek Indonesia}

Berdasarkan hasil analisis, rasio arus kas bebas PT Gudang Garam, Tbk yang terdaftar di Bursa Efek Indonesia befluktuasi cenderung menurun. Rasio arus kas bebas tahun 2011, 2012, 2013, 2014 dan 2015 memiliki nilai negatif dan di bawah standar $\leq 0$, yang artinya bahwa fleksibilitas keuangan PT Gudang Garam, Tbk tidak berkembang dan kas bersih yang diperoleh dari aktivitas operasi tidak cukup menjamin kewajiban lancarnya setelah dikurangi pengeluaran modal dan pembayaran dividen.

Nilai arus kas bebas PT Gudang Garam, Tbk terendah terjadi pada tahun 2011, tahun 2013 dan di tahun 2014 juga terjadi penurunan arus kas bebas yang cukup drastis. Hal ini disebabkan oleh kas bersih yang diperoleh dari aktivitas operasi tidak cukup unduk mendanai aktvitas investasi dan aktivitas pendanaan (pengeluaran modal dan pembayaran dividen).

Berdasarkan hasil analisis, secara keseluruhan arus kas bebas cenderung mengalami peningkatan. Namun peningkatan ini masih di bawah standar $\leq 0$. Sebaiknya kas bersih yang dihasilkan lebih kecil dibandingkan dengan kegiatan operasi perusahaan. Semakin besar arus kas bebas semakin baik kinerja keuangan. Sebaliknya, semakin kecil arus kas bebas semakin tidak baik kinerja keuangan. Hal ini dapat dikatakan bahwa kinerja keuangan belum baik karena rasio arus kas bebas $\leq 0$. Sebaiknya perubahan yang terjadi dalam saldo utang dividen (meskipun termasuk sebagai kewajiban lancar) tidak diperhitungkan dalam melaporkan arus kas bersih dari aktivitas operasi, mengingat bahwa utang dividen timbul sebagai akibat dari aktivitas pembiayaan perusahaan dan besarnya dividen yang diumumkan tidak memengaruhi besarnya laba/rugi bersih.

\section{d. Kinerja Keuangan PT Gudang Garam, Tbk yang Terdaftar di Bursa Efek Indonesia}

Berdasarkan hasil analisis, kinerja keuangan dikatakan kurang baik. Rasio likuiditas keuangan, fleksibilitas keuangan dan arus kas bebas rata-rata di bawah standar $\leq 1$. Untuk rasio likuiditas keuangan dan fleksibilitas keuangan standar $\geq 1$. Sedangkan untuk rasio arus kas bebas standar $\geq 0$. Untuk rasio likuiditas keuangan tahun 2011 sampai 2015 kinerja keuangan dinyatakan kurang baik karena rata-rata di bawah standar $\leq 1$. Hal ini disebabkan peningkatan kewajiban lancar semakin besar. Perusahaan tidak mampu memenuhi kewajiban lancar yang akan segera jatuh tempo menggunakan kas bersih yang tersediah dari aktivitas operasi.

Rasio fleksibilitas keuangan dari tahun 2011-2015 rata-rata $\leq 1$ dan kinerja keuangan dinyatakan kurang baik. Hal ini disebabkan kenaikan kewajiban lancar semakin tinggi yang mengakibatkan kemampuan perusahaan memenuhi kewajiban lancarnya dengan jangka waktu jatuh tempo lebih panjang dengan kas bersih yang diperoleh dari aktivitas operasi semakin kecil. 
Sedangkan untuk rasio arus kas bebas dari tahun 2011 sampai dengan tahun $2015 \leq 0$ dan kinerja keuangan dinyatakan belum baik. Perusahaan tidak mampu memenuhi kegiatan pendanaan dan investasi dengan kas bersih yang diperoleh dari aktivitas operasi.

\section{KESIMPULAN DAN SARAN}

\section{Kesimpulan}

a. Berdasarkan hasil analisis likuiditas PT Gudang Garam, Tbk yang terdaftar di Bursa Efek Indonesia dari tahun 2011 sampai 2015 cenderung mengalami peningkatan namun peningkatan ini masih di bawah standar $\leq 1$. Nilai likuiditas keuangan PT Gudang Garam, Tbk terendah terjadi pada tahun 2011. Hal ini disebabkan oleh penerimaan kas dari pelanggan lebih kecil daripada peningkatan pembayaran kas kepada pemasok dan karyawan selalu meningkat dari tahun ke tahun. Dalam pembayaran bunga juga mengalami peningkatan ditambah lagi pembayaran pajak penghasilan badan di tahun 2011 merupakan jumlah yang paling tinggi dibandingkan tahun-tahun yang lain.

b. Berdasarkan hasil analisis fleksibilitas PT Gudang Garam, Tbk yang terdaftar di Bursa Efek Indonesia dari tahun 2011 sampai 2015 cenderung mengalami peningkatan dan di atas rata-rata. Nilai terendah terjadi pada tahun 2011. Hal ini disebabkan oleh semakin besarnya total kewajiban yang harus dibiayai perusahaan menggunakan kas bersih yang diperoleh dari aktivitas operasi.

c. Berdasarkan hasil analisis rasio arus kas bebas PT Gudang Garam, Tbk yang terdaftar di Bursa Efek Indonesia terendah terjadi tahun 2014. Pada tahun 2014 juga terjadi penurunan arus kas bebas yang cukup drastis dari tahun 2013. Hal ini disebabkan karena terjadinya kenaikan pada pembayaran dividen dan pengeluaran kas. Sedangkan kas bersih yang diperoleh dari aktivitas operasi yang digunakan untuk kegiatan tersebut mengalami penurunan.

d. Berdasarkan keseluruhan dari hasil analisis rasio likuiditas keuangan, fleksibilitas keuangan dan arus kas bebas PT Gudang Garam, Tbk yang terdaftar di Bursa Efek Indonesia kinerja keuangan perusahaan belum baik. Karena hasil analisis rasio cenderung di bawah rata-rata.

\section{Saran}

a. Sebaiknya perusahaan lebih memperhatikan lagi keadaan yang lebih baik saat akan melakukan pinjaman kepada pihak yang berkepentingan agar kas bersih yang dihasilkan dari aktivitas operasi bisa disesuaikan untuk memenuhi kewajiban perusahaan saat operasi.

b. Sebaiknya perusahaan dapat mengurangi pembayaran kas kepada pemasok agar dapat mengurangi penimbunan kelebihan persedian dalam perusahaan tersebut karena pembayaran kas kepada pemasok selalu meningkat dari tahun 2011 sampai tahun 2015. Dan pihak manajemen harus lebih memperhatikan pengeluaran hutang dalam perusahaan agar perusahaan mengetahui seberapa besar pinjaman yang diberikan perusahaan kepada nasabah.

c. Sebaiknya perusahaan tidak memperhitungkan perubahan yang terjadi dalam saldo utang dividen dalam melaporkan arus kas bersih dari aktivitas operasi, mengingat bahwa utang dividen timbul sebagai akibat dari aktivitas pembiayaan perusahaan dan besarnya dividen yang diumumkan tidak mempengaruhi besarnya laba/rugi bersih.

\section{E. DAFTAR PUSTAKA}

Baridwan, Zaki. 2004. Intermediate Accounting. Edisi Kedelapan, Cetakan Pertama. Yogyakarta: BPFE.

Kasmir. 2010. Pengantar Manajemen Keuangan. Edisi Pertama, Cetakan ke-2. Jakarta: Kencana Prenada Media Group.

Kieso., E. Donald., Jerry J. Weygand.,dan Terry D. Walfield. 2002. Akuntansi Intermediate. Edisi Kesepuluh, Jilid 1. Jakarta:Erlangga.

2002. Akuntansi Intermediate. Edisi Kesepuluh, Jilid 3. Jakarta: Erlangga.

Martani, Dwi dkk. 2012. Akuntansi Keuangan Dan Manajemen Berbasis PSAK, Jakarta: Salemba Empat.

Mulyadi. 2001. Sistem Akuntansi, edisi ketiga. Cetakan ketiga. Jakarta: Salemba Empat.

Rudianto. 2012. Pengantar Akuntansi, Konsep Penyusunan Laporan Keuangan, Adaptasi IFRS. Jakarta: Erlangga.

2013. Akuntansi Manajemen: Informasi Untuk Pengambilan Keputusan Strategis. Jakarta: Erlangga.

Wild, John J., K. R. Subramanyam., dan Robert. F. Halsey. 2005. Analisis Laporan Keuangan. Edisi 8, Buku 1. Jakarta: Salemba Empat. 